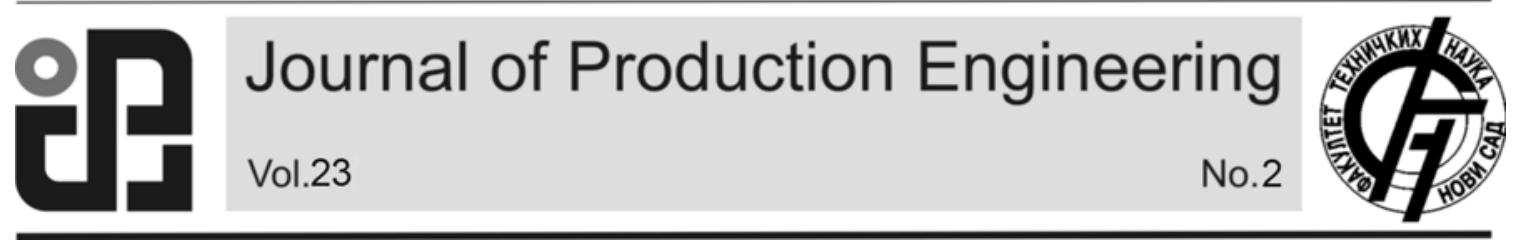

JPE (2020) Vol.23 (2)

Tripathy, M., Khanna, P.

Original Scientific Paper

\title{
MATHEMATICAL ANALYSIS OF BEAD PARAMETERS IN MIG WELDING OF STAINLESS STEEL 304
}

Received: 16 July 2020 / Accepted: 13 September 2020

\begin{abstract}
M I G$ welding process has gained prominence over the past few decades owing to its versatility, portability, all position weldability and ease of automation. These attributes of MIG welding make it suitable for usage in fabrication and automotive sectors over the other conventional welding processes. The present work is aimed to study the effects of varying the controllable input parameters on the weld bead shape, obtained by MIG welding on Stainless Steel-304. Statistical technique of Design of Experiments has been used for systematic and structured way of experimentation. The linear two factor interactive and quadratic effects of welding parameters and the response on the parameters work predicted by developing mathematical models by using center composite rotatable design technique. ANOVA analysis was carried to check the adequacy of the developed models. Response surface methodology was used to analyze the effects of input variables on the outputs through graphical means.
\end{abstract}

Key words: Bead geometry, input parameters, design of experiments, mathematical models.

Matematička analiza parametara koji utiču na oblik kuglice zavara kod MIG zavarivanja nerđajućeg čelika 304. Proces MIG zavarivanja dobio je na značaju tokom poslednjih nekoliko decenija zahvaljujući svojoj svestranosti, prenosivosti, zavarivanju svih položaja i lakoći automatizacije. Ovi atributi MIG zavarivanja čine ga pogodnim za upotrebu u proizvodnim $i$ automobilskim sektorima u odnosu na druge konvencionalne postupke zavarivanja. Cilj ovog rada je da prouči efekte promene ulaznih parametara koji se mogu kontrolisati na oblik kuglice zavara, dobijene MIG zavarivanjem na nerđajućem čeliku 304. Statistička tehnika dizajniranja eksperimenata korišćena je za sistematičan i strukturiran način eksperimentisanja. Korišćen je linearni dvofaktoni interaktivni matematički modela dobijen na bazi centralnog kompozionog dizajn plana eksperimenta sa kvadratnim efektima ispitivanih parametara zavarivanja i odzivnom površinom. Analiza ANOVA je sprovedena kako bi se proverila adekvatnost razvijenih modela. Metodologija odzivne površine korišćena je za analizu efekata ulaznih promenljivih sa odgovarajućim grafičkim prikazom.

Ključne reči: Geometrija zrna, ulazni parametri, dizajn eksperimenata, matematički modeli.

\section{INTRODUCTION}

Several situations arise in industrial practice which call for joining of materials [1]. MIG Welding is a popular joining process in industries like automotive, rail coach and general fabrication owing to its versatility, low cost, adaptability to automation and consistent quality weld joints [2]. Stainless steel is a suitable material for industrial applications due to its attractive physical properties. The stainless steel 304 is extensively used in fabrication industries involved in food processing, chemical, structural and other engineering applications [3]. The present material that is austenitic stainless steel offers excellent corrosion resistance, formability and good weldability, making it a preferred choice for food processing and dairy applications. Welded joints on this material for such applications therefore require specific attention to the quality and reliability which can further be ensured by having optimal values of weld bead parameters [4]. Various aspects of MIG welding on this material have been investigated by many researches in the past but relatively less investigative work is reported on the bead geometry aspects of this material [5], which has prompted the authors to carry out the present work. Appearance of a weld bead not only tells us about the welding skill used but it can also give a lot of information regarding the strength, load carrying capacity of the joint. From the past studies, it has been established that the weld bead parameters are dependent on the input parameters which therefore play an important role in deciding the quality of a weld [6]. The interaction of these input parameters during welding affect the bead parameters and the final performance characteristics of the weld. Therefore, it is necessary to establish mathematical relationship between the input parameters and the bead parameters so that an optimal combination of the latter may be preselected to attain the desired bead parameters and hence the desired mechanical properties of the resulting weld [7]. The important bead parameters are; depth of weld penetration $(\mathrm{P})$ which is the depth to which the base plate is melted, weld width (W), which is the width of the weld bead visible from the top and height of reinforcement (h), which is the height of the weld deposition above the top surface of the plate. These parameters constitute and define the bead's physical size which ultimately decide the performance of the weld joint in service conditions. The important bead parameters are shown in fig 1 . The input weld parameters which are found to affect these responses are Wire feed rate (WFR), Voltage (V), Welding speed (S), 
Nozzle to plate distance (NPD), Torch angle $(\theta)$ and gas flow rate $(G)$ respectively.

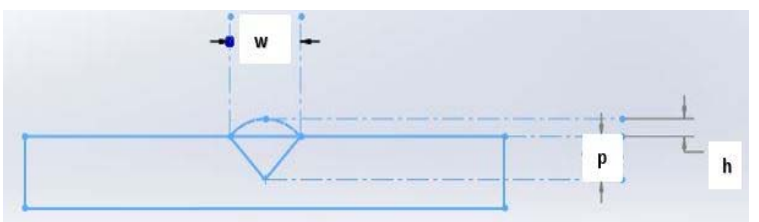

Fig. 1. Bead parameters

\section{EXPERIMENTAL SETUP}

The experimental setup shown in fig 2 shows a MIG welding power source of capacity 400amps with flat V-I characteristics. A wire feed unit, a mechanized welding unit which facilitates to attain welding speeds from 0 $50 \mathrm{~cm} / \mathrm{min}$ in a step-less manner. Industrially pure argon gas was used as shielding medium. Filler wire of stainless steel $308 \mathrm{~L}$ with diameter $1.2 \mathrm{~mm}$ was used. A gas flow rate of $15 \mathrm{~L} / \mathrm{min}$ was maintained throughout the experimental runs.

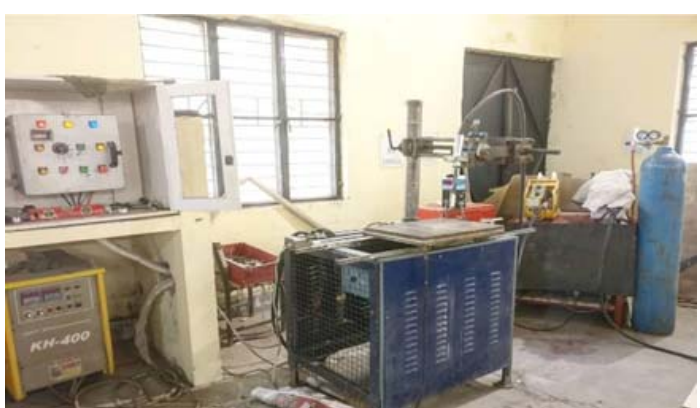

Fig. 2. Experimental Setup

\section{INVESTIGATION PLAN}

The following steps were undertaken to conduct the proposed research work:
(1) Identification of input parameters

(2) Estimation of working ranges of these parameters

(3) Development of Design Matrix

(4) Conduction of experiments

(5) Development of Mathematical Model

(6) Testing the adequacy of developed model

(7) Results and their analysis

(8) Conclusions

\subsection{Identification of important input parameters}

A number of trial runs were carried out to identify and select individually controllable input parameters that can have effect on the bead parameters. Based on these trial runs, the shortlisted input parameters were; Wire Feed Rate (WFR), Voltage (V), Welding Speed (S), Nozzle to Plate Distance (NPD) and Torch Angle $(\theta)$ respectively. Gas flow rate was found not to have profound effect on the bead parameters.

\subsection{Estimation of working ranges of parameters}

To determine the operating ranges of the above identified parameters, trials were conducted by varying a single parameter at a time and keeping the others constant at some intermediate value. In this way, the lower and upper values of input parameters were established by keeping the following considerations in mind.

a. The weld bead is uniform

b. No spatters

c. No burn-through, undercuts or overlaps

d. No visible porosity

e. No cracks

The lower values were coded as $(-2)$ and the upper values as $(+2)$ and the intermediate values as $(+1),(-1)$ with (0) as the central value. The coded values of all the input parameters are indicated in table 1.

\begin{tabular}{|l|l|l|l|l|l|l|l|}
\hline Weld parameters & Symbol & Unit & $\mathbf{( - 2 )}$ & $\mathbf{( - 1 )}$ & $\mathbf{( 0 )}$ & $\mathbf{( + 1 )}$ & $\mathbf{( + 2 )}$ \\
\hline Wire feed rate & WFR & $(\mathrm{m} / \mathrm{min})$ & 0.3 & 0.6 & 0.9 & 1.2 & 1.5 \\
\hline Voltage & $\mathrm{V}$ & $(\mathrm{volts})$ & 14 & 16 & 18 & 20 & 22 \\
\hline Welding speed & $\mathrm{S}$ & $(\mathrm{cm} / \mathrm{min})$ & 25 & 30 & 35 & 40 & 45 \\
\hline Nozzle to plate distance & NPD & $(\mathrm{mm})$ & 10 & 12.5 & 15 & 17.5 & 20 \\
\hline Torch angle & $\theta$ & $\left({ }^{\circ}\right)$ & 70 & 80 & 90 & 100 & 110 \\
\hline
\end{tabular}

Table 1. Input parameters and their operating ranges

\subsection{Design Matrix}

In order to carry out the investigation in a systematic manner, the experiments are to be conducted in a logically structured way so that all the independent and interactive effects of the input parameters on the output responses can be analyzed. For this, a statistical technique of Design of Experiments was used. A total of
32 experimental runs were made as per the design matrix given in table 2 . The samples were cut out of these weldments and prepared and etched to reveal the bad geometry as shown in fig. 3. The penetration depth, width and the reinforcement height were then measured by using a profile projector and their respective values are recorded in table 2 .

\begin{tabular}{|l|l|l|l|l|l|l|l|l|}
\hline Run & $\begin{array}{c}\text { Wire } \\
\text { Feed Rate } \\
(\mathbf{m} / \mathbf{m i n})\end{array}$ & $\begin{array}{c}\text { Voltage } \\
(\text { volts })\end{array}$ & $\begin{array}{c}\text { Welding } \\
\text { speed } \\
(\mathbf{c m} / \mathbf{m i n})\end{array}$ & $\begin{array}{c}\text { NPD } \\
(\mathbf{m m})\end{array}$ & $\begin{array}{c}\text { Torch } \\
\text { angle }\left({ }^{\circ}\right)\end{array}$ & $\begin{array}{c}\text { Depth of } \\
\text { Penetration } \\
(\mathbf{m m})\end{array}$ & $\begin{array}{c}\text { Weld } \\
\text { Width } \\
(\mathbf{m m})\end{array}$ & $\begin{array}{c}\text { Height of } \\
\text { Reinforcement } \\
(\mathbf{m m})\end{array}$ \\
\hline 1 & 0 & 0 & 0 & 0 & 0 & 3.40 & 9.50 & 3.30 \\
\hline 3 & -1 & 1 & -1 & 1 & 1 & 2.90 & 12.00 & 2.70 \\
\hline
\end{tabular}




\begin{tabular}{|c|c|c|c|c|c|c|c|c|}
\hline 4 & 0 & 0 & 0 & 2 & 0 & 1.60 & 8.60 & 3.20 \\
\hline 5 & -1 & 1 & 1 & 1 & -1 & 2.80 & 10.20 & 2.40 \\
\hline 6 & 0 & 0 & 0 & 0 & 0 & 3.50 & 10.20 & 3.40 \\
\hline 7 & -1 & 1 & 1 & -1 & 1 & 1.70 & 4.60 & 3.30 \\
\hline 8 & 1 & -1 & 1 & -1 & 1 & 1.50 & 9.05 & 2.40 \\
\hline 9 & 2 & 0 & 0 & 0 & 0 & 3.80 & 11.10 & 3.40 \\
\hline 10 & 1 & 1 & -1 & 1 & -1 & 2.80 & 10.32 & 2.70 \\
\hline 11 & 0 & 0 & 0 & 0 & 2 & 1.90 & 11.00 & 3.00 \\
\hline 12 & 1 & 1 & -1 & -1 & 1 & 2.45 & 10.85 & 3.10 \\
\hline 13 & -1 & -1 & -1 & -1 & 1 & 1.80 & 9.14 & 2.80 \\
\hline 14 & 0 & 0 & 2 & 0 & 0 & 1.80 & 9.50 & 2.00 \\
\hline 15 & 0 & 0 & 0 & 0 & -2 & 1.80 & 9.20 & 2.70 \\
\hline 16 & 0 & 0 & 0 & 0 & 0 & 2.45 & 9.34 & 3.43 \\
\hline 17 & 1 & -1 & -1 & 1 & 1 & 2.10 & 9.70 & 3.50 \\
\hline 18 & 0 & 0 & 0 & 0 & 0 & 3.50 & 10.20 & 3.40 \\
\hline 19 & 0 & 0 & 0 & 0 & 0 & 3.50 & 10.20 & 3.40 \\
\hline 20 & 1 & -1 & 1 & 1 & -1 & 1.60 & 8.50 & 2.90 \\
\hline 21 & 0 & 0 & -2 & 0 & 0 & 2.70 & 11.00 & 2.60 \\
\hline 22 & -1 & -1 & 1 & 1 & 1 & 1.40 & 8.95 & 2.80 \\
\hline 23 & 0 & 0 & 0 & 0 & 0 & 3.10 & 9.40 & 3.20 \\
\hline 24 & -1 & -1 & 1 & -1 & -1 & 2.10 & 8.40 & 2.30 \\
\hline 25 & 1 & 1 & 1 & 1 & 1 & 2.28 & 10.00 & 2.76 \\
\hline 26 & 0 & 0 & 0 & -2 & 0 & 2.10 & 8.68 & 2.78 \\
\hline 27 & 0 & -2 & 0 & 0 & 0 & 1.39 & 8.90 & 2.87 \\
\hline 28 & 0 & 2 & 0 & 0 & 0 & 3.02 & 7.93 & 3.16 \\
\hline 29 & -1 & -1 & -1 & 1 & -1 & 1.85 & 8.83 & 2.49 \\
\hline 30 & 1 & -1 & -1 & -1 & -1 & 1.80 & 9.10 & 3.50 \\
\hline 31 & -2 & 0 & 0 & 0 & 0 & 2.89 & 10.00 & 3.30 \\
\hline 32 & 1 & 1 & 1 & -1 & -1 & 1.84 & 10.10 & 2.63 \\
\hline
\end{tabular}

Table 2. The Design Matrix

\subsection{Conduction of experiments}

The 32 experiments were conducted at the combinations of parameters as suggested in the Design Matrix. The experiments were conducted in a random manner in order to avoid any systematic error in the machine. Once the weldments were ready, test samples of size $50 \mathrm{~mm} \times 30 \mathrm{~mm}$ were cut from the center of the weldments. The weldments were further polished and treated with etchants. Fig. 3 indicates the etched surface revealing the weld bead with clear view of all the parameters.

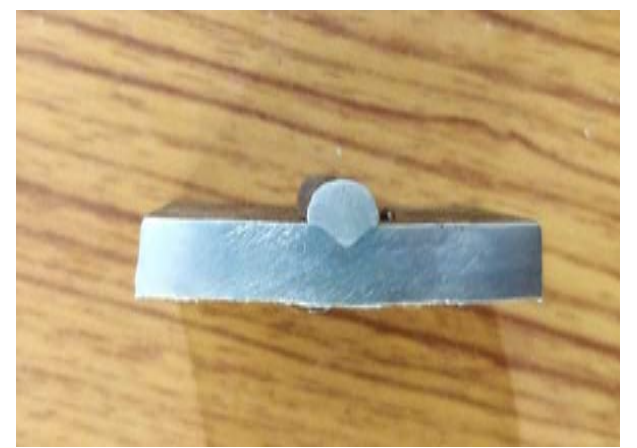

Fig. 3. Etched surface revealing the bead

\subsection{Development of Mathematical Model}

The bead characteristics as shown in fig 3 were then measured by using the technique of shadowgraphy. The results obtained were inserted in table 2 . The data was then analyzed by using Design of Experiments software which developed mathematical models for the response parameters as given below:

Depth of penetration $=3.23+0.05 * \mathrm{~W}+0.34 * \mathrm{~V}-$ $0.195 * \mathrm{~S}+0.04 * \mathrm{~N}-0.03 * \mathrm{~A}-0.01 * \mathrm{~W} * \mathrm{~V}-0.06 * \mathrm{~W} * \mathrm{~S}$ $+0.01 * \mathrm{~W} * \mathrm{~N}+0.1 * \mathrm{~W} * \mathrm{~A}-0.06 * \mathrm{~V} * \mathrm{~S}+0.16 * \mathrm{~V} * \mathrm{~N}+$ $0.03 * \mathrm{~V} * \mathrm{~A}-0.01 * \mathrm{~S} * \mathrm{~N}-0.11 * \mathrm{~S} * \mathrm{~A}+0.02 * \mathrm{~N} * \mathrm{~A}+$ $0.03 * \mathrm{~W}^{2}-0.25 * \mathrm{~V}^{2}-0.24 * \mathrm{~S}^{2}-0.34 * \mathrm{~N}^{2}-0.34 * \mathrm{~A}^{2}$

Weld Width $=9.84+0.32 * \mathrm{~W}+0.17 * \mathrm{~V}+0.53 * \mathrm{~S}+$ $0.30 * \mathrm{~N}+0.1 * \mathrm{~A}+0.22 * \mathrm{~W} * \mathrm{~V}+0.33 * \mathrm{~W} * \mathrm{~S}-0.53 * \mathrm{~W} * \mathrm{~N}$ $+0.25 * \mathrm{~W} * \mathrm{~A}-0.38 * \mathrm{~V} * \mathrm{~S}+0.43 * \mathrm{~V} * \mathrm{~N}-0.31 * \mathrm{~V} * \mathrm{~A}+$ $0.22 * \mathrm{~S} * \mathrm{~N}-0.51 * \mathrm{~S} * \mathrm{~A}+0.41 * \mathrm{~N} * \mathrm{~A}+0.15 * \mathrm{~W}^{2}-$ $0.38 * \mathrm{~V}^{2}+0.07 * \mathrm{~S}^{2}-0.32 * \mathrm{~N}^{2}+0.03 * \mathrm{~A}^{2}$

Height of reinforcement $=3.34+0.08 * \mathrm{~W}+0.01 * \mathrm{~V}-$ $0.14 * \mathrm{~S}+0.01 * \mathrm{~N}+0.09 * \mathrm{~A}-0.12 * \mathrm{~W} * \mathrm{~V}-0.12 * \mathrm{~W} * \mathrm{~S}+$ $0.07 * \mathrm{~W} * \mathrm{~N}-0.09 * \mathrm{~W}^{*} \mathrm{~A}+0.09 * \mathrm{~V} * \mathrm{~S}-0.12 * \mathrm{~V} * \mathrm{~N}+$ $0.05 * \mathrm{~V} * \mathrm{~A}+0.07 * \mathrm{~S} * \mathrm{~N}+0.03 * \mathrm{~S} * \mathrm{~A}+0.06 * \mathrm{~N} * \mathrm{~A}+$ $0.01 * \mathrm{~W}^{2}-0.07 * \mathrm{~V}^{2}+0.25 * \mathrm{~S}^{2}-0.08 * \mathrm{~N}^{2}-0.12 * \mathrm{~A}^{2}$

\subsection{Testing the model's adequacy}

The model's adequacy was checked by analysis of variance (ANOVA) technique. All the calculated Fratio values were found to be less than their standard tabulated values. Another indication of model's adequacy is that the p-values of all the models are less than 0.05 . The sufficiently high value of $R^{2}$ with 
adjusted $\mathrm{R}^{2}$ in its close proximity is yet another indicator of model's adequacy. Finally, the adequate precision greater than 4 in all the cases suggests high signal-to-noise value and adequacy of the models. The model summary is given in table 3 .

\begin{tabular}{|c|c|c|c|c|c|c|}
\hline Parameter & F-value & $\mathrm{p}$-value & $\mathrm{R}^{2}$ & Adjusted $\mathrm{R}^{2}$ & $\begin{array}{c}\text { Adequate } \\
\text { Precision }\end{array}$ & Model Adequacy \\
\hline Penetration & 0.78 & 0.007 & 0.890 & 0.692 & 7.08 & Adequate \\
\hline Width & 4.68 & 0.011 & 0.877 & 0.653 & 11.33 & Adequate \\
\hline Reinforcement & 4.45 & 0.001 & 0.95 & 0.86 & 12.48 & Adequate \\
\hline
\end{tabular}

Table 3. ANOVA Summary

\subsection{Results and Discussions}

\subsubsection{Interaction effects of $V$ and wire WFR on depth of penetration $(P)$}

To keep the paper within reasonable limits, only a few of the interaction plots are being explained. Fig. 4 shows the interaction effects of $\mathrm{V}$ and WFR on (P). It can be seen that both of these parameters have positive effect on (P). The reason could be that both WFR and V increase is associated with the increase in heat input and arc force thereby leading to increased penetration

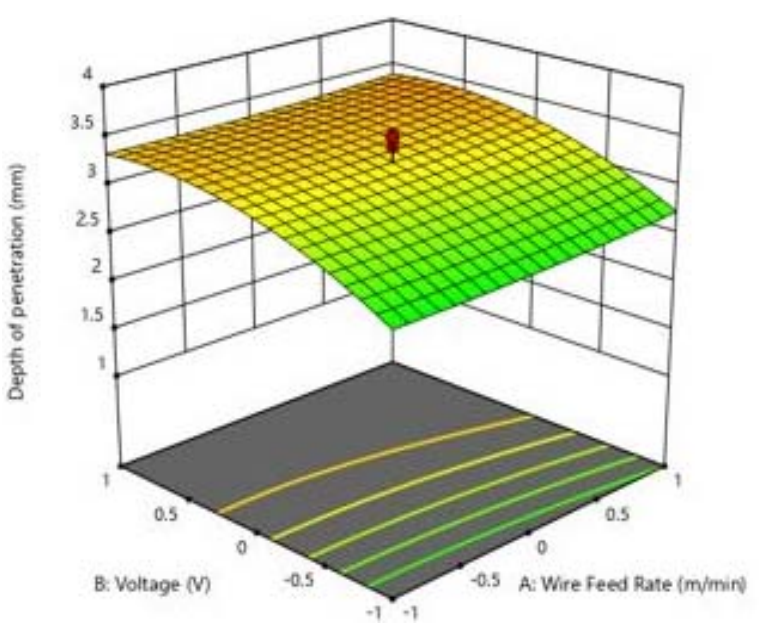

Fig.4. Interaction effects of $\mathrm{V}$ and WFR on (P)

\subsubsection{Interaction effects of $S$ and WFR on (P)}

Fig. 5 shows the interaction effects of $S$ and WFR on (P). It can be seen that for all values of WFR, the (P) decreases with increase of $\mathrm{S}$ since with increase of speed, heat input to the weld pool reduces thereby decreasing the $(\mathrm{P})$. For all values of $\mathrm{S}$, the $(\mathrm{P})$ increases with increase in WFR for the reason explained in section 4.1.

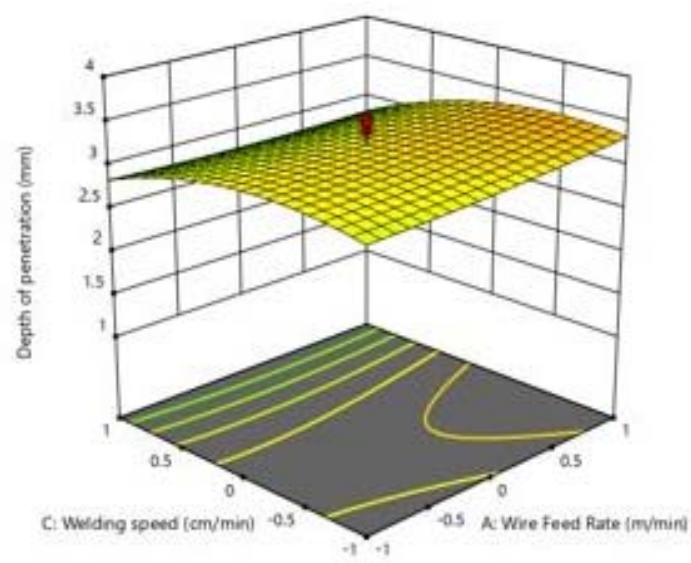

Fig. 5. Interaction effects of $\mathrm{S}$ and WFR on (P)

\subsubsection{Interaction effects of $S$ and WFR on (W)}

Fig. 6 shows the interaction effects of S and WFR on (W). It can be seen that for all values of WFR, the (W) decreases with increase of $\mathrm{S}$. The reason is that with increase of speed, heat input to the weld pool reduces thereby decreasing the (W). For all values of welding speed, the weld width increases with increase in WFR for the same reason.

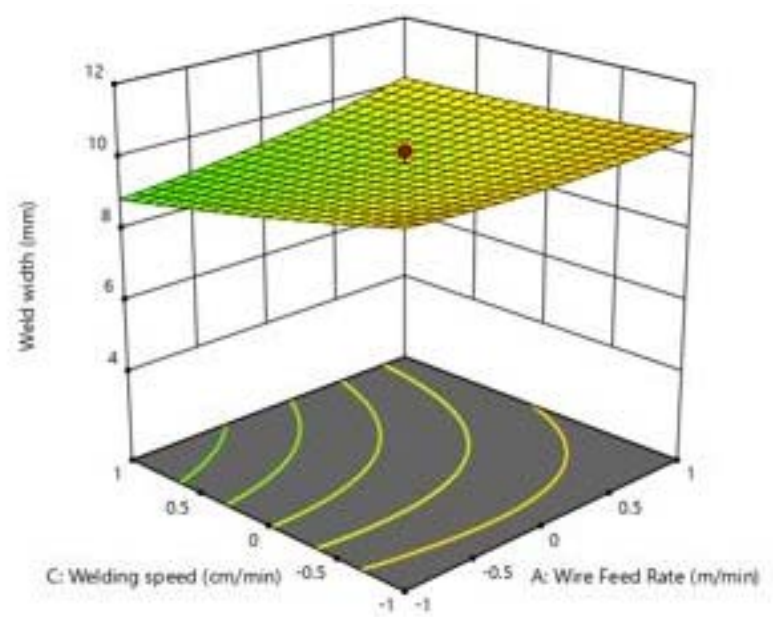

Fig. 6. Interaction effects of S and WFR on (W)

\subsubsection{Interaction effects of $V$ and WFR on (h)}

In Fig 7, it can be seen that at lower values of $\mathrm{V}$, the (h) increased with increase in WFR because of more melting of filler metal with increase in welding current whereas at higher values of $\mathrm{V}$, the effect is reversed probably because of higher spreading effect of voltage.

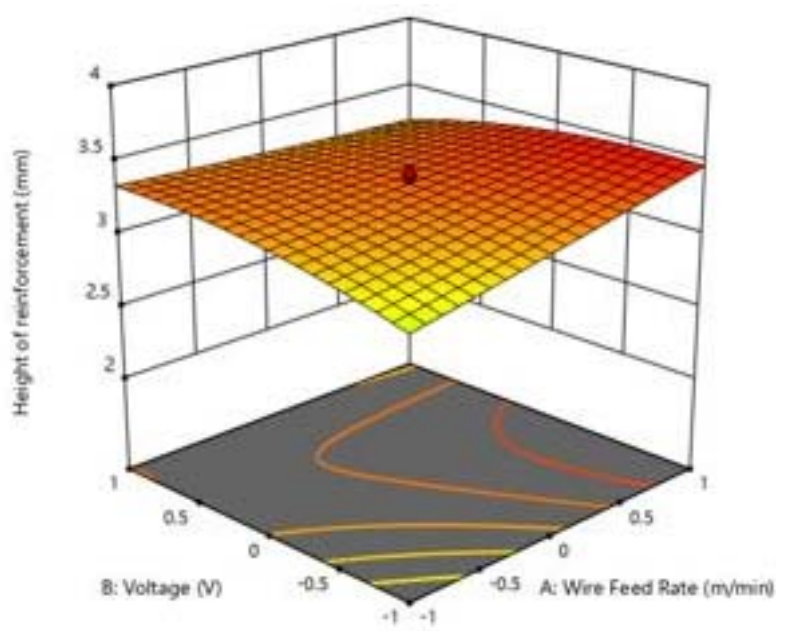

Fig. 7. Interaction effects of V and WFR on (h) 


\section{CONCLUSIONS}

From the investigative work carried out so far, the following are the conclusions:

- The input parameters selected for the study have significant effect on the responses.

- The Central Composite Rotatable Design Technique of Design of Experiments has proved to be a useful and effective tool in the development of mathematical models of such applications

- The depth of penetration was found to increase with WFR, V and NPD whereas it decreased with increase in $\mathrm{S}$ and $\theta$.

- $\quad$ Reinforcement increased with WFR and NPD whereas it decreased with increasing V, $\theta$ and Welding Speed.

- Weld width increased with WFR, V, NPD and Torch angle whereas it decreased with increase in welding speed

\section{REFERENCES}

[1] Kumar, LS., Verma, SM., Prasad, PR., Kumar, PK., Shanker, TS.: Experimental Investigation for Welding Aspects of AISI 304 \& 316 by Taguchi Technique for the Process of TIG \& MIG Welding. International Journal of Engineering Trends and Technology, 2:28-33, 2011.

[2] Salleh, MS., Ramli, MI., Yahaya, SH.: Study on mechanical properties and microstructure analysis of AISI 3041 stainless steel weldments, Journal of
Mechanical Engineering and Technology, 3:71-82, 2011.

[3] Maurya, BK., Pratap, B., Kumar, A., Rana, G.: Experimental Analysis of Dissimilar Metal Welds of Mild Steel and Stainless Steel, International Research Journal of Engineering and Technology, 4:1744-8, 2017.

[4] Ghosh, N., Pal, PK., Nandi, G.: Parametric optimization of MIG welding on 316L austenitic stainless steel by Taguchi method, Archives of Material Science and Engineering, 79:27-36, 2016.

[5] Mondal, P., Bose, D.: Optimization of the Process Parameters for MIG Welding of AISI 304 and IS 1079 Using Fuzzy Logic Method, International Research Journal of Engineering and Technology, 2:483-8, 2015.

[6] Singhmar, M., Verma, N.: Experimental study for Welding Aspects of Austenitic Stainless Steel (AISI 304) on Tensile Strength by Taguchi Technique. International Journal of Mechanical Engineering and Robotics Research, 4:493-503, 2015.

[7] Sonasale, P.: An Approach to Optimize MIG Welding Parameters by Using Design of Experiments, IOSR Journal of Mechanical and Civil Engineering, 11:72-84, 2014.

Authors: Mayank Tripathy, Student, Pradeep Khanna, Associate Prof., Division of MPAE, Netaji Subhas University of Technology, New Delhi-110078, India.

E-mail: mayanktripathy.1998@gmail.com 4.khanna@gmail.com 